\title{
Pengaruh Motivasi Terhadap Kinerja Karyawan BRI Syariah Magetan
}

\author{
Wahna Widhianingrum* \\ Universitas Muhammadiyah Ponorogo, Indonesia \\ *Email korenpondensi: wwahna@yahoo.com
}

Recieved 26-10-2017| Revised 14-11-2017 | Accepted 28-11-2017

\begin{abstract}
Abstrak
Motivasi merupakan suatu pendorong bagi karyawan agar bekerja lebih giat dan sungguh-sungguh dalam mencapai tujuan yang diinginkan. Pemberian motivasi yang tepat akan mendorong karyawan bekerja lebih efektif dan efisien sehingga diharapkan kinerja karyawan akan meningkat. Penelitian ini mempunyai tujuan untuk mengetahui apakah ada pengaruh motivasi terhadap kinerja karyawan. Dan apa saja bentuk motivasi yang dapat digunakan untuk memotivasi kinerja karyawan, dan untuk mengetahui faktor apa yang paling signifikan mempengaruhi kinerja karyawan. Penelitian dilakukan pada BRI Syariah Magetan. Dalam melakukan penelitian penulis menggunakan metode analisis regresi linier berganda, koefisien determinasi, dan uji $F$ dan uji t untuk melakukan pengujian hipotesis. Data yang dikumpulkan melalui kuesioner yang dibagikan kepada 50 responden karyawan BRI Syariah Magetan. Dari ketiga variabel independen yang diuji secara individual, bentuk motivasi yang paling dominan dalam mempengaruhi kinerja karyawan. Semua variabel independen berpengaruh positif terhadap kinerja karyawan BRI Syariah Magetan.
\end{abstract}

Katan kunci: Motivasi, Kinerja, Karyawan, Efektif, Efisien

Saran sitasi: Widhianingrum, W. (2017). Pengaruh Motivasi Terhadap Kinerja Karyawan BRI Syariah Magetan. Jurnal Ilmiah Ekonomi Islam, 3(03), 193-198. doi:http://dx.doi.org/10.29040/jiei.v3i03.124

DOI: http://dx.doi.org/10.29040/jiei.v3i03.124

\section{Pendahuluan}

Motivasi merupakan suatu pendorong bagi karyawan agar bekerja lebih giat dan sungguhsungguh dalam mencapai tujuan yang diinginkan. Motivasi juga mempengaruhi efektivitas seorang manajer. Karena kemampuan manajer untuk memotivasi , mempengaruhi, mengarahkan dan berkomunikasi yang baik dengan para bawahannya (karyawan) akan menentukan efektivitas manajer tersebut. Motivasi juga merupakan kegiatan yang mengakibatkan, mcenyalurkan, dan memelihara perilaku manusia. Motivasi ini merupakan subyek yang penting bagi manajer.

Hasil studi Lubis (2008), menemukan bahwa bahwa pelatihan dan motivasi kerja berpengaruh positif dan signifikan terhadap kinerja karyawan PT Perkebunan Nusantara IV (Persero) Medan. Disamping itu motivasi yang diberikan oleh pimpinan atau perusahaan juga memiliki peran yang penting untuk meningkatkan semangat kerja dan komitmen karyawan terhadap perusahaan yang akhirnya juga berhasil meningkatkan kinerja karyawan. Devi (2009), menunjukkan bahwa; 1) terdapat pengaruh positif dan signifikan antara kepuasan kerja dengan kinerja karyawan. 2) terdapat pengaruh positif dan signifikan antara motivasi dengan kinerja karyawan. 3) terdapat pengaruh positif dan signifikan antara kepuasan kerja dengan komitmen organisasional.

4) terdapat pengaruh positif antara motivasi 
dengan komitmen organisasional. 5) terdapat pengaruh positif antara komitmen organisasional dengan kinerja karyawan namun tidak signifikan.

Hasil penelitian Sutrischastini (2015) menunjukkan adanya pengaruh positif antara motivasi kerja terhadap kinerja pegawai Kantor Sekretariat Daerah Kabupaten Gunungkidul, maka Kantor Sekretariat Daerah Kabupaten Gunungkidul harus selalu meningkatkan kesadaran akan manajemen (pemimpinan) dalam upaya melakukan pembinaaan pegawai secara terus menerus sehingga prestasi kerja pegawai merasa dihargai.

Dalam penulisan ini, penulis menganalisis pengaruh motivasi terhadap kinerja karyawan BRI Syariah Magetan. Manfaat penelitian ini dapat diketahui apakah motivasi akan mempengaruhi kinerja karyawan.

\section{Landasan Teori}

Motivasi berasal dari kata latin movere yang berarti dorongan atau menggerakkan. Motivasi (motivation) dalam manajemen hanya ditujukan pada sumber daya manusia umumnya dan bawahan khususnya. Berikut ini beberapa pengertian motivasi dari para ahli, sebagai berikut:

a. Berendoom, Stainer dan Russel (1993), mendefinisikan "motivasi" adalah kondisi mental yang mendorong aktivitas dan memberi energi yang mengarah kepada pencapaian kebutuhan memberi kepuasan atau mengurangi ketidakseimbangan".

b. Hasibuan (2010) mendefinisikan "motivasi adalah pemberian daya penggerak yang menciptakan kegairahan kerja seseorang, agar mereka mau bekerja sama secara produktif berhasil mencapai dan mewujudkan tujuan yang telah ditentukan."

c. Gibson et al. (1996) mendefinisikan "motivasi adalah kekuatan yang mendorong seseorang karyawan yang menimbulkan dan mengarahkan perilaku". Motivasi merupakan hasrat di dalam seseorang yang menyebabkan orang tersebut melakukan tindakan. Motivasi merupakan penggerak yang mengarahkan pada tujuan, dan itu jarang muncul dengan sia-sia. Kata butuh, ingin, hasrat dan penggerak semua sama dengan motif yang asalnya dari kata motivasi.

d. Flippo (2003) bahwa motivasi adalah directing or motivation is essence, it is a skill in aligning employee and organization interest so thet behavior result in eachievement of emrployee want simultaneously with attainment of organizational objectives

Menurut Mangkunegara (2009b) bahwa teori-teori motivasi dapat dikategorikan menjadi tiga kelompok, yaitu:

a. Teori motivasi dengan pendekatan isi, lebih banyak menekankan pada faktor apa yang membuat karyawan melakukan suatu tindakan tertentu. Contoh teori motivasi Abraham Maslow. Seorang berperilaku/ bekerja, karena dorongan untuk memenuhi bermacam-macam kebutuhan. Kebutuhan didefinisikan suatu kesejangan atau pertentangan yang di alami antara suatu kenyataan dengan dorongan yang ada dalam diri. Apabila pegawai kebutuhannya tidak terpenuhi maka pegawai tersebut akan menunjukkan perilaku kecewa. Sebaliknya jika kebutuhannya terpenuhi maka pegawai tersebut akan memperlihatkan perilaku yang gembira sebagai manifestasi dari rasa puasnya. Lima kebutuhan manusia menurut Maslow, antara lain: physiological needs (kebutuhan fisik), security or safety needs (kebutuhan keselamatan), affiliation or acceptance (kebutuhan sosial), esteem or status needs (kebutuhan akan penghargaan prestise), dan self actualization (aktualisasi diri) (Maslow, 2010).

b. Teori motivasi dengan pendekatan penguat, lebih menekankan pada faktor-faktor yang dapat meningkatkan suatu tindakan dilakukan atau yang dapat mengurangi suatu tindakan. Contoh teori motivasi dari Skinner (operant conditioning). Skinner, 1983) mengemukakan bahwa pendekatan teori motivasi yang mempengaruhi dan merubah perilaku kerja yaitu pembentukan perilaku atau sering 
disebut dengan istilah seperti behavior modification, positive reinforecement, dan skinnerian conditioning. Pendekatan ini didasarkan terutama atas hukum pengaruh (law of effect), yang menyatakan bahwa perilaku yang diikuti dengan konsekuensi-konsekuensi pemuasan cenderung diulang, sedangkan perilaku yang diikuti konsekuensi hukuman cenderung tidak diulang.Dengan demikian perilaku individu di waktu mendatang dapat diperkirakan atau dipelajari dari pengalaman di waktu yang lalu.

c. Teori motivasi dengan pendekatan proses, tidak hanya menekankan pada faktor apa yang membuat karyawan bertindak, tetapi juga bagaimana karyawan tersebut termotivasi. Contoh teori motivasi berprestasi dari Clelland. Motivasi berprestasi dapat diartikan sebagai suatu kekuatan yang mendorong diri seseorang untuk mengerjakan atau melaksanakan sesuatu

Sementara Kinerja dapat diartikan sebagai hasil kerja yang dicapai oleh seseorang atau organisasi dalam jangka waktu tertentu. Kinerja juga merupakan suatu fungsi dari motivasi dan kemampuan seseorang untuk menyelesaikan tugas atau pekerjaan. Kinerja adalah hasil kerja secara kulaitas dan kuantitas yang dicapai oleh seorang pegawai dalam melaksanakan tugasnya sesuai dengan tanggung jawab yang diberikan kepadanya (Listianto dan Setiaji, 2006, Mangkunegara, 2009). Menurut ahli lain, Bernadin dan Rusel (Gomes, 2000) kinerja adalah hasil kerja yang dihasilkan dari fungsi suatu pekerjaan tertentu atau kegiatan selama satu periode tertentu.

\section{Metode Penelitian}

Variabel bebas (X) dalam penelitian ini meurpakan faktor-faktor motivasi dengan subsub variabel: $\left(\mathrm{X}_{1}\right)$ Bonus, $\left(\mathrm{X}_{2}\right)$ Penghargaan, $\left(\mathrm{X}_{3}\right)$ Prestasi, adapun variabel terikat (dependent) yaitu merupakan variabel yang dipengaruhi oleh variabel bebas yaitu Kinerja (Y). Teknis analisis data dalam penelitian ini menggunakan Analisis Regresi Berganda (Ghozali, 2006), yang meliputi uji T dan uji F. Selain itu juga dilakukan uji asumsi klasik yang meliputi uji multikolinearitas dan uji autokorelasi.

\section{Hasil dan Pembahasan}

Analisis regresi berganda digunakan untuk mengetahui pengaruh variabel Bonus $\left(\mathrm{X}_{1}\right)$, Penghargaan $\left(\mathrm{X}_{2}\right)$ dan Prestasi $\left(\mathrm{X}_{3}\right)$ terhadap variabel kinerja karyawan (Y). Hasil perhitungan regresi berganda variabel Bonus $\left(\mathrm{X}_{1}\right)$, Penghargaan $\left(\mathrm{X}_{2}\right)$ dan Prestasi $\left(\mathrm{X}_{3}\right)$ terhadap variabel kinerja karyawan $(\mathrm{Y})$ didapat hasil sebagaimana Tabel 1.

Tabel 1. Hasil Analisis Regresi Linier Berganda

\begin{tabular}{cccc}
\hline Variabel & Koefisien & t hitung & Sig. \\
\hline Konstan & 2,153 & 2,308 & 0,026 \\
$\mathrm{X}_{1}$ & 0,222 & 1,830 & 0,074 \\
$\mathrm{X}_{2}$ & 0,251 & 1,227 & 0,226 \\
$\mathrm{X}_{3}$ & 0,014 & 0,07 & 0,945 \\
\hline
\end{tabular}

Dependen variabel: Kinjerja Karyawan

Dengan demikian diperoleh persamaan regresi linier berganda sebagai berikut:

$Y=2,153+0,222 X_{1}+0,251 X_{2}+0,014 X_{3}$

Hasil dari analisis tersebut dapat diinterpretasikan sebagai berikut:

a. Konstanta sebesar 2,153 menunjukan bahwa apabila Bonus $\left(\mathrm{X}_{1}\right)$, Penghargaan $\left(\mathrm{X}_{2}\right)$, Prestasi $\left(\mathrm{X}_{3}\right)$ dianggap tetap, tetapi dipengaruhi oleh variabel diluar model, maka diperkirakan Kinerja Karyawan (Y) akan naik sebesar 2,153

b. Koefisien regresi Bonus $\left(\mathrm{X}_{1}\right)$ sebesar 0,222 artinya, Bonus meningkat satu satuan maka Kinerja Karyawan (Y) akan mengalami kenaikan sebesar 0,222 dengan asumsi variabel lain bernilai tetap.

c. Koefisien regresi Penghargaan $\left(\mathrm{X}_{2}\right)$, sebesar 0,251 artinya, Penghargaan meningkat satu satuan maka Kinerja Karyawan (Y) akan mengalami kenaikan sebesar 0,251 dengan asumsi variabel lain bernilai tetap.

d. Koefisien regresi Prestasi $\left(\mathrm{X}_{3}\right)$ sebesar 0,014 artinya, Prestasi meningkat satu satuan maka Kinerja Karyawan (Y) akan mengalami kenaikan sebesar 0,014 dengan asumsi variabel lain bernilai tetap. 
Berdasarkan kesimpulan diatas faktor bonus, faktor penghargaan, faktor prestasi mempunyai hubungan yang positif dengan kinerja karyawan. Hubungan positif ini menunjukkan bahwa faktor bonus, faktor penghargaan, dan faktor prestasi berubah searah dengan perubahan kinerja karyawan. Sementara untuk melihat hubungan antara variabel independen dan dependent dapat dilihat dari analisis korelasi ganda. Adapun hasil analisis korelasi Ganda, sebagaimana pada Tabel 2.

Tabel 2. Hasil Analisis Korelasi Ganda

\begin{tabular}{ccc}
\hline $\mathrm{R}$ & $\mathrm{R}$ square & Adjusted R Square \\
\hline 0,400 & 0,160 & 0,105 \\
\hline
\end{tabular}

Berdasarkan Tabel 2 diperoleh hasil $\mathrm{R}$ sebesar 0,400. Hal ini menunjukan bahwa terjadi hubungan yang sedang antara Bonus, Penghargaan dan Prestasi terhadap Kinerja Karyawan. Sementara uji koefisien determinasi $\left(\mathrm{R}^{2}\right)$ yang pada pada intinya untuk mengukur proporsi atau persentase sumbangan variabel bebas yaitu variabel Pengaruh Bonus $\left(\mathrm{X}_{1}\right)$, Pengaruh Penghargaan $\left(\mathrm{X}_{2}\right)$, Pengaruh Prestasi $\left(\mathrm{X}_{3}\right)$ terhadap Kinerja Karyawan (Y) secara bersama-sama. Dari Tabel 2, dapat dilihat bahwa nilai Adjusted $R$ Square adalah 0,105 Adjusted $R$ Square disebut juga dengan koefisien determinasi sehingga dalam hal ini berarti $10,5 \%$ menunjukan bahwa persentase sumbangan pengaruh variabel independen (Bonus, Penghargaan dan Prestasi terhadap variabel dependen (Kinerja Karyawan) sebesar 10,5\%. Sedangkan sisanya sebesar $89,5 \%$ dipengaruhi atau dijelaskan oleh variabel lain yang tidak dimasukkan dalam penelitian ini.

Sementara uji asumsi klasik salah satunya meliputi deteksi Multikolinear. Gejala multikolinearitas dapat dilihat dari besarnya nilai Tolerance dan VIF. Tolerance mengukur variabilitas variabel terpilih yang tidak dijelaskan oleh variabel independen lainnya. Nilai umum yag biasa dipakai adalah nilai Tolerance $<0,1$ atau nilai VIF > 10, maka terjadi gejala multikolinearitas. Sebaliknya jika nilai Tolerance $>0,1$ atau nilai VIF $<10$, maka tidak terjadi gejala multikolinearitas. Adapun hasil uji VIF dan Tolerance sebagaimana pada Tabel 3.
Tabel 3. Hasil Uji VIF dan Tolerance

\begin{tabular}{ccc}
\hline Variabel & Tolerance & VIF \\
\hline $\mathrm{X}_{1}$ & $0,654^{*}$ & $1,530^{* *}$ \\
$\mathrm{X}_{2}$ & $0,904^{*}$ & $1,106^{* *}$ \\
$\mathrm{X}_{3}$ & $0,669^{*}$ & $1,495^{* *}$ \\
\hline
\end{tabular}

Keterangan: *Tolerance $>0,1 ; *$ VIF $<10$

Adapun asumsi lainnya yaitu uji deteksi Autokorelasi, dengan tujuan untuk mendeteksi ada tidaknya autokorelasi, melalui tabel DurbinWatson, dimana secara umum dapat diambil patokan yaitu:

- Jika angka DW $<2,2$ berarti tidak terjadi autokorelasi.

- Jika angka DW > 2,2, berarti terjadi autokorelasi.

Untuk hasil uji autokorelasi dalam penelitian ini dapat dilihat pada tabel berikut:

Tabel 4. Hasil Uji Autokorelasi

\begin{tabular}{cccc}
\hline $\mathrm{R}$ & $\mathrm{R}$ square & $\begin{array}{c}\text { Adjusted } \mathrm{R} \\
\text { Square }\end{array}$ & $\begin{array}{c}\text { Durbin- } \\
\text { watson }\end{array}$ \\
\hline 0,400 & 0,160 & 0,105 & 1,977 \\
\hline
\end{tabular}

Dari Tabel 4 di atas menunjukan nilai DW sebesar 1,977. Karena nilai tersebut berada di bawah 2,2 maka menunjukkan tidak adanya gejala autokorelasi pada model regresi ini.

\subsection{Uji Simultan (Uji F)}

Untuk mengetahui apakah variable independent yang terdiri dari Bonus $\left(\mathrm{X}_{1}\right)$, Penghargaan $\left(\mathrm{X}_{2}\right)$ dan Prestasi $\left(\mathrm{X}_{3}\right)$ secara bersamasama berpengaruh atau tidak berpengaruh terhadap Kinerja Karyawan (Y), maka harus diuji signifikansinya dengan menggunakan Uji $F$ dengan tingkat signifikansi 0,05.

Tabel 5. Hasil Uji F

\begin{tabular}{lrrcc}
\hline \multicolumn{1}{c}{ Model } & $\begin{array}{r}\text { Sum of } \\
\text { squares }\end{array}$ & Df & F & Sig. \\
\hline Regression & 5,021 & 3 & 2,924 & $0,044^{* *}$ \\
Residual & 26,362 & 46 & & \\
Total & 31,347 & 49 & & \\
\hline
\end{tabular}

Keterangan: ** signifikan pada level $\alpha 0,05$

Dari hasil uji Anova pada Tabel 5, menunjukkan angka sig sebesar 0,044, pengambilan keputusan juga dapat dilakukan dengan melihat probabilitasnya dimana nilai sig 0,000<0,05 sehingga $\mathrm{H}_{0}$ ditolak dan $\mathrm{H}_{\mathrm{a}}$ diterima. Artinya Variabel Pengaruh bonus $\left(\mathrm{X}_{1}\right)$, pengaruh 
penghargaan $\left(\mathrm{X}_{2}\right)$ dan pengaruh prestasi $\left(\mathrm{X}_{3}\right)$ secara bersama-sama berpengaruh terhadap variabel dependen Kinerja Karyawan.

\subsection{Uji Parsial (Uji t)}

Untuk mengetahui apakah motivasi berupa bonus $\left(\mathrm{X}_{1}\right)$, penghargaan $\left(\mathrm{X}_{2}\right)$ dan prestasi $\left(\mathrm{X}_{3}\right)$ secara parsial berpengaruh signifikan atau tidak terhadap kinerja karyawan (Y), maka harus diuji signifikansinya dengan menggunakan uji $t$ dengan tingkat signifikansi 0,05 .

\begin{tabular}{cccc}
\multicolumn{4}{c}{ Tabel 6. Hasil Uji t } \\
\hline Variabel & Koefisien & t hitung & Sig. \\
\hline Konstan & 2,153 & 2,308 & 0,026 \\
$\mathrm{X}_{1}$ & 0,222 & 1,830 & 0,074 \\
$\mathrm{X}_{2}$ & 0,251 & 1,227 & 0,226 \\
$\mathrm{X}_{3}$ & 0,014 & 0,07 & 0,945 \\
\hline
\end{tabular}

Berdasarkan Tabel 6, dapat diketahui hasil uji signifikan secara parsial koefisien regresi variabel bonus, penghargaan dan prestasi tidak berpengaruh terhadap kinerja karyawan. Untuk lebih jelasnya dapat dilihat per variabel sebagai berikut:

\subsection{Pengaruh Variabel Bonus Terhadap Kinerja Karyawan}

Nilai signifikansi variabel bonus sebesar $0,074>0,05$ sehingga $\mathrm{H}_{0}$ diterima maka pengaruh bonus secara statistik tidak berpengaruh secara parsial terhadap kinerja karyawan. Artinya bonus tidak menjadi faktor yang berpengaruh terhadap kinerja karyawan. Semakin tinggi bonus yang diberikan tidak memberikan dampak atau perubahan pada nilai kinerja. Namun demikian, secara teori bonus menjadi pendorong untuk meningkatkan kinerja, artinya hasil penelitian ini tidak sejalan teori motivasi yang medorong dalam meningkatkan kinerja karyawan, begitu juga dengan hasil studi empiris yang tentang motivasi yang telah dilakukan oleh Lubis (2008) dan Devi (2009).

\subsection{Pengaruh Variabel Penghargaan Terha- dap Kinerja Karyawan}

Nilai signifikansi variabel penghargaan sebesar 0,226>0,05 sehingga $\mathrm{H}_{0}$ diterima maka pengaruh penghargaan secara statistik tidak berpengaruh secara parsial terhadap kinerja karyawan. Artinya penghargaan tidak menjadi faktor yang berpengaruh terhadap kinerja karyawan. Semakin tinggi penghargaan yang diberikan tidak memberikan dampak atau perubahan pada nilai kinerja. Namun demikian, secara teori penghargaan menjadi pendorong untuk meningkatkan kinerja, artinya hasil penelitian ini tidak sejalan teori motivasi yang medorong dalam meningkatkan kinerja karyawan, begitu juga dengan hasil studi empiris yang tentang motivasi yang telah dilakukan oleh Lubis (2008) dan Devi (2009).

\subsection{Pengaruh Variabel Prestasi Konsumen Terhadap Kinerja Karyawan \\ Nilai signifikansi variabel prestasi konsumen sebesar 0,945 > 0,05 sehingga $\mathrm{H}_{0}$ diterima maka} pengaruh prestasi secara statistik tidak berpengaruh secara parsial terhadap kinerja karyawan. Artinya prestasi konsumen tidak menjadi faktor yang berpengaruh terhadap kinerja karyawan. Semakin tinggi prestasi konsumen yang diberikan tidak memberikan dampak atau perubahan pada nilai kinerja. Namun demikian, secara teori prestasi konsumen menjadi pendorong untuk meningkatkan kinerja, artinya hasil penelitian ini tidak sejalan teori motivasi yang medorong dalam meningkatkan kinerja karyawan, begitu juga dengan hasil studi empiris yang tentang motivasi yang telah dilakukan oleh Lubis (2008) dan Devi (2009).

\section{Kesimpulan}

Berdasarkan hasil penelitian dapat disimpulkan bahwa; 1) Berdasarkan hasil persamaan regresi menunjukkan bahwa prediksi pengaruh motivasi terhadap kinerja karyawan bersifat positif. Artinya motivasi berpengaruh baik terhadap kinerja karyawan BRI Syariah Magetan. 2) Berdasarkan kriteria interpretasi koefisien determinasi menunjukkan, bahwa terdapat pengaruh motivasi terhadap kinerja karyawan, akan tetapi terdapat pengaruh yang kecil. Sedangkan faktor lain yang tidak terdefinisi, cukup besar mempengaruhi variabel kinerja karyawan BRI Syariah Magetan; 3) Berdasarkan hasil penelitian secara serempak, ada pengaruh 
yang signifikan antara variabel motivasi kerja berupa (bonus, penghargaan dan prestasi) terhadap kinerja karyawan BRI Syariah Magetan. 3) Berdasarkan hasil penelitian secara parsial, ketiga variabel motivasi berupa (bonus, penghargaan, dan prestasi) tidak berpengaruh secara parsial terhadap kinerja karyawan BRI Syariah Magetan

\section{UCAPAN TERIMAKASIH}

Penulis ingin menyampaikan ucapan terimakasih kepada Universitas Muhammadiyah Ponorogo yang telah mendukung selesainya penelitian ini.

\section{DAFTAR PUSTAKA}

Berendoom, B., Stainer dan Russel. (1993), Human Resources Management, New York: McGrow Hill.

Devi, Eva Kris Diana (2009),"Analisis Pengaruh Kepuasan Kerja Dan Motivasi Terhadap Kinerja Karyawan Dengan Komitmen Organisasional Sebagai Variabel Intervening (Studi Pada Karyawan Outsourcing PT Semeru Karya Buana Semarang)",Tesis tak diterbitkan, Universitas Diponegoro Semarang.

Flippo, Edwin B. (2003). Pengembangan Sumber Daya Manusia, cetakan kesepuluh. Jakarta: Erlangga.

Ghozali, I. (2006). Aplikasi Analisis Multivariate dengan Program SPSS. Semarang: Badan Penerbit Undip. Semarang

Gibson, James L., John M. Vancevich dan James H. Donelly (1996), Organisasi dan Manajemen: Perilaku, Struktur, Proses, Jakarta: Binarupa Aksara
Gomes, Faustino Cardoso. (2000). Manajemen Sumber Daya Manusia, Cetakan. Keempat. Yogyakarta: Penerbit Andi

Listianto, Toni dan Setiaji Bambang (2006). Pengaruh motivasi, kepuasan, dan disiplin kerja karyawan (Studi kasus di Lingkungan Pegawai Kantor PDAM Kota Surakarta), http: eprints.ums.ac.id_6_ Toni Lysanto. New doc

Lubis, Khairul Akhir (2008),Pengaruh Pelatihan Dan Motivasi Kerja Terhadap Kinerja Karyawan PT Perkebunan Nusantara IV (Persero) Medan, Tesis tak dipublikasikan, Sekolah Pascasarjana Universitas Sumatera Utara

Mangkunegara, A.A. Anwar Prabu (2009b), Manajemen Sumber Daya Manusia Perusahaan. Bandung: PT Remaja Rosdakarya

Mangkunegara, A.A. Anwar Prabu (2009). Evaluasi Kinerja SDM. Bandung: Refika Aditama

Maslow, Abraham H. (2010). Motivation and Personality. Jakarta: Rajawali

Skinner, B.F. (1938). The Behavior of Organisms: An Experimental Analysis. Cambridge, Massachusetts: B.F. Skinner Foundation.

Sutrischastini, Ary. 2015. Pengaruh Motivasi Kerja Terhadap Kinerja Pegawai Kantor Sekretariat Daerah Kabupaten Gunungkidul. Jurnal Kajian Bisnis Vol. 23, No. 2, JULI 2015. STIE Widya Wiwaha. Yogyakarta. 